\title{
Multicriteria Decision Model and Thermal Pretreatment of Hotel Food Waste for Robust Output to Biogas: Case Study from City of Jaipur, India
}

\author{
Paras Gandhi, ${ }^{1}$ Kunwar Paritosh, ${ }^{1}$ Nidhi Pareek, ${ }^{2}$ Sanjay Mathur, ${ }^{1}$ Javier Lizasoain, ${ }^{3,4}$ \\ Andreas Gronauer, ${ }^{3}$ Alexander Bauer, ${ }^{3}$ and Vivekanand Vivekanand (i) ${ }^{1}$ \\ ${ }^{1}$ Centre for Energy and Environment, Malaviya National Institute of Technology, Jaipur 302017, Rajasthan, India \\ ${ }^{2}$ Department of Microbiology, School of Life Sciences, Central University of Rajasthan, Bandarsindri, Kishangarh, \\ Ajmer 305801, Rajasthan, India \\ ${ }^{3}$ University of Natural Resources and Life Sciences, Vienna, Department of Sustainable Agricultural Systems, \\ Institute of Agricultural Engineering, Konrad-Lorenz-Strasse 24, 3430 Tulln, Austria \\ ${ }^{4}$ Biogest Energie- und Wassertechnik GmbH, Büropark Donau, Inkustraße 1-7/4/2. OG, 3400 Klosterneuburg, Austria \\ Correspondence should be addressed to Vivekanand Vivekanand; vivekanand.cee@mnit.ac.in
}

Received 29 December 2017; Revised 20 April 2018; Accepted 7 August 2018; Published 16 September 2018

Academic Editor: José L. Campos

Copyright (C) 2018 Paras Gandhi et al. This is an open access article distributed under the Creative Commons Attribution License, which permits unrestricted use, distribution, and reproduction in any medium, provided the original work is properly cited.

The anaerobic batch test $\left(45\right.$ days at $37^{\circ} \mathrm{C}$ ) was performed to describe the effect of thermal pretreatment at moderate temperatures $\left(60,80\right.$, and $\left.100^{\circ} \mathrm{C}\right)$ over durations of 10 and 20 minutes on the enhancement of biogas production using hotel food waste from city of Jaipur, India. The results showed that the total cumulative biogas production with thermal pretreatment $\left(100^{\circ} \mathrm{C}, 10 \mathrm{minutes}\right)$ was $41 \%$ higher than the control. Also, this alternative gets first rank using multicriteria decision making model, VIKOR. This outcome was obtained due to the enhancement of degradation of organic compounds such as protein and volatile solids that occurred in the linear trend. Modified Gompertz and Logistic models were used to study the effect of different pretreatment parameters on lag time and biogas yield. Scanning electron microscopy and Fourier transform infrared spectroscopy were also employed to investigate the effect of thermal pretreatment on the physiochemical properties of food waste.

\section{Introduction}

Together with the rapid growth of urban population and changes in the typical eating patterns, management of food waste $(\mathrm{FW})$ has become an issue of international level $[1,2]$. In India only, $40 \%$ of produced food is lost and wasted, prior to consumption every year [3]. Around the globe, 12-30\% FW is generated annually (Figure 1). This huge amount of waste, if either cannot be utilised fruitfully or disposed of carelessly, can hamper public health and generate number of challenges in terms of environmental protection and denotes noteworthy amount of potential energy $[1,2]$.

In India, the increase in foreign tourist arrivals has pushed the hospitality sector for enhancing quality services in order to fulfil customer's satisfaction. This leads to the growth of hotels as well as FW generation, which has not been explored earlier. Rajasthan, which has a significant share of foreign tourism in the country with $7.2 \%$ Foreign Tourist Arrivals (FTA) in 2013 [4], has witnessed rapid growth in hotel infrastructure resulting in a hike of $53.6 \%$ in number of hotels available from 2006 to 2016 (Ministry of Tourism, 2016; [5]). This rapid growth calls for another challenge of managing the huge lump of waste and its proper disposal. In most instances, the FW, which consists of rich nutrients capable of providing valuable products and energy, is wasted by being dumped along with municipal solid waste (MSW) due to lack of segregation. Recently, our group has published a comprehensive review regarding the quantification of FW generated from hotels and its energy potential in Jaipur, India (Gandhi et al., 2017). 


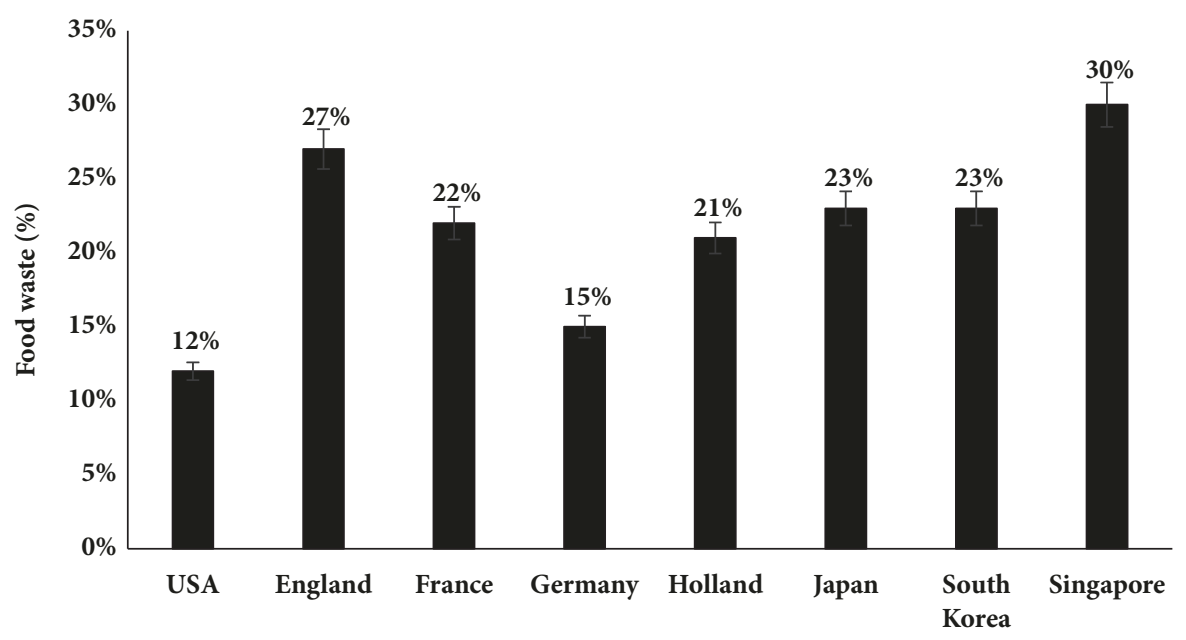

FIGURE 1: Food waste percentage in different countries [13].

FW from hotels of Jaipur contains variety of materials, some of which are not suitable for anaerobic digestion (AD), namely, egg shells, coffee grounds, tissue papers, and bone, that have different physical and chemical characteristics. Due to presence of above undesirable components, it is not easy for microbes to degrade these complex and hard materials. Therefore, to improve the biodegradability of these materials and provide readily available organics for maximum biogas recovery, pretreatment becomes necessary prior to $\mathrm{AD}$ [6]. Among numerous pretreatment technologies, here more focus is given on thermal pretreatment technology of low severity such as liquid hot water (LHW).

LHW pretreatment is one of the preferred pretreatment methods that can easily enhance the access of sugars to microbes by solubilizing them using higher temperature [7]. Generation of organic acids, such as acetic acid, after hydrolysis, further enhances the rate of conversion of complex sugars to simple sugars [8]. The main advantage of this pretreatment is that it is chemical free and does not need corrosion resistive material for reactors. Kuo and Cheng [9] reported the impact of thermal pretreatment on the $\mathrm{AD}$ of kitchen waste at different temperatures $\left(37,50\right.$, and $\left.60^{\circ} \mathrm{C}\right)$ to understand the effect on hydrolysis. As a result, pretreatment at $60^{\circ} \mathrm{C}$ was desirable with a total chemical oxygen demand (TCOD) removal efficiency of $79.2 \%$. Another study from Ariunbaatar et al. [10] revealed that pretreatment at lower temperature $\left(50\right.$ and $80^{\circ} \mathrm{C}$ ) for shorter duration, i.e., less than 12 and 1.5 hours, enhances the biogas yield by $40 \%$ due to higher solubilization, whereas $\mathrm{Ma}$ et al. [11] obtained an increase of $24 \%$ in biomethane production at $120^{\circ} \mathrm{C}$ due to enhanced biodegradation of FW. Li et al. [12] and Jin et al., (2016) investigated the effect of thermal pretreatment not only on kitchen waste at low $\left(55-90^{\circ} \mathrm{C}\right)$ and high (120 and $160^{\circ} \mathrm{C}$ ) temperatures on the biogas production, but also on the degradation efficiency of fat, oil and grease, crude protein, volatile solids, volatile fatty acids, etc.

The degradation of fermentable sugars due to high severity of thermal pretreatment can be controlled by maintaining the optimum $\mathrm{pH}$ with the addition of base [14]. Thus, to reduce the application of chemicals while mitigating the deterioration of fermentable sugars, milder pretreatment methods should be followed.

The impacts of thermal pretreatment on the chemical and physical properties of three municipal solid wastes (MSW), namely, kitchen waste, vegetable waste, and waste activated sludge, were explored by Liu et al. [15]. Outcomes revealed that thermal pretreatment $\left(175^{\circ} \mathrm{C}, 60 \mathrm{~min}\right)$ diminished viscosity and increased COD, dissolvable sugar, and proteins. In the study, a decrease of 7.9 and $11.7 \%$ in the methane yield was observed for kitchen waste and vegetable waste. The authors ascribed this phenomenon and occurrence to the arrangement of an intractable copolymer, melanoidin. Under comparative working conditions $\left(170^{\circ} \mathrm{C}, 1 \mathrm{~h}\right)$, Qiao et al., [16] found that both biogas and methane generation from anaerobically treated waste diminished by $3.4 \%$ and $7.5 \%$, respectively. Ma et al. [11] acquired $24 \%$ enhancement in biomethane generation with $\mathrm{FW}$ pretreated at $120^{\circ} \mathrm{C}$.

In spite of the advantages, thermal pretreatment has some disadvantages, i.e., (a) less stability, (b) formation of inhibitors due to side reactions, and (c) higher operating cost $[17,18]$. The rate of biochemical reaction controls the hydrolysis and acidogenesis steps, which can be accelerated at high temperatures. The higher amount of fatty acids, ammonia, and so on causes inhibition to methanogenesis process [19].

A series of batch experiments were conducted to measure the biogas potential and to compare the effect of thermal pretreatment using the hotel FW as the substrate. Both the increased hydrolysis and improved solubilization depends on temperature and time [20]. In the present study, the batch $\mathrm{AD}$ of pretreated and untreated hotel FW was performed to derive the critical parameters, namely, temperature and time affecting biogas production, and to relate them to the impact of severity on the chemistry of substrate. Physical and chemical fingerprinting was performed for the untreated and pretreated substrate using SEM and FTIR, respectively. Energy analysis was also performed using the data generated to study the economics of the pretreatment process. 
TABle 1: Analysis of the FW and inoculum.

\begin{tabular}{lcc}
\hline Parameters & FW $^{\mathbf{a}}$ & Inoculum \\
\hline Proximate analysis & & \\
pH & $5.1 \pm 0.2$ & 7.8 \\
Total solids (\%) & $35.8 \pm 0.5$ & $6.4 \pm 0.2$ \\
VS (\%, wet basis) & $34.3 \pm 0.4$ & $4.4 \pm 0.8$ \\
TCOD (mg/L) & $229.5 \pm 38.7$ & - \\
SCOD (mg/L) & $79.3 \pm 4.3$ & - \\
Protein (mg/L) & $20.3 \pm 0.3$ & - \\
Ultimate analysis & & $35.1 \pm 1.2$ \\
Carbon (\%) & $49.5 \pm 1.6$ & $4.3 \pm 0.4$ \\
Hydrogen (\%) & $9.9 \pm 0.2$ & $1.7 \pm 0.2$ \\
Nitrogen (\%) & $2.7 \pm 0.4$ & $58.8 \pm 0.9$ \\
Oxygen (\%) & $36.1 \pm 1.7$ & - \\
Sulphur (\%) & $0.3 \pm 0.0042$ & 20.64 \\
C/N & 18.33 & \\
\hline
\end{tabular}

${ }^{\mathrm{a}}$ Each parameter was measured in triplicates: SCOD, soluble COD; TCOD, total COD.

TABLE 2: Severity factor and pretreatment conditions of hotel food waste.

\begin{tabular}{lcr}
\hline S1. No. & Severity factor & Pretreatment conditions \\
\hline 1 & 0.0 & Untreated \\
2 & 1.7 & $60^{\circ} \mathrm{C}, 10 \mathrm{~min}$ \\
3 & 2.0 & $60^{\circ} \mathrm{C}, 20 \mathrm{~min}$ \\
4 & 2.3 & $80^{\circ} \mathrm{C}, 10 \mathrm{~min}$ \\
5 & 2.6 & $80^{\circ} \mathrm{C}, 20 \mathrm{~min}$ \\
6 & 2.9 & $100^{\circ} \mathrm{C}, 10 \mathrm{~min}$ \\
7 & 3.2 & $100^{\circ} \mathrm{C}, 20 \mathrm{~min}$ \\
\hline
\end{tabular}

\section{Material and Methods}

2.1. Food Waste and Inoculum Characteristics. FW used in this study was collected on the weekly basis from the cafeteria and kitchens of the six hotels reputed with star category in Jaipur. After manual sorting, FW was separated from undesirable parts (such as egg shells, bones, tissue papers, peels, and kernels). Collected FW mainly consisted of carbohydrates, proteins, and fats, being the major components of rice, vegetables and fruits, bread, cooked pulses, and meat. All parts of collected food were mixed in a kitchen blender and stored at $4^{\circ} \mathrm{C}$ in a refrigerator after crushing into particles with an average size of 1-2 $\mathrm{mm}$. Table 1 shows the basic characteristics of FW and inoculum used in this experiment.

Inoculum was taken from the anaerobic digester plant (Rajasthan Gau Sewa Sangh, Durgapura, Jaipur, Rajasthan), which was using cow manure at the mesophilic temperature range, with initial $\mathrm{pH}$ of 7.8. Volatile solid (VS) concentration of the inoculum was $68.75 \% \mathrm{VS} / \mathrm{TS}$. Before the experiment, it was stored in a container at room temperature for five days to acclimatize and starve it prior to using in $\mathrm{AD}$ batch experiments.

2.2. Thermal Pretreatment. Thermal pretreatment was performed using hot water bath (Sanco, India) and $50 \mathrm{~g}$ of a representative sample of FW (wet mass) and $50 \mathrm{ml}$ of distilled water to provide uniform heating for pretreatment making the solid to liquid ratio of $1: 1(\mathrm{w} / \mathrm{v})$. The water bath was kept on until the target temperature reached to 60,80 , and $100^{\circ} \mathrm{C}$ in the beaker and held for the selected durations of time (10 and $20 \mathrm{~min}$ ) for each temperature (Table 2). During the pretreatment process, the mixture was stirred continuously until the set period completed. After the different pretreatments were carried out, the samples were kept in the refrigerator at $4^{\circ} \mathrm{C}$ till further use. The liquid part was separated from the insoluble remains for further analysis.

To determine how the combined effect of temperature (T) and time (t) affects FW [21], severity factor (Table 2) was calculated using the following equation:

$$
\log R_{0}\left\{R_{0}\right\}=t * \exp \left(\frac{T-100}{w}\right)
$$

where $t$ is pretreatment time, $\mathrm{T}$ is pretreatment temperature, and $\mathrm{w}=14.75$ is an empirical parameter.

2.3. Anaerobic Digestion and Biogas Production. The FW digestion experiment was performed in the $610 \mathrm{~mL}$ serum bottle with active volume of $400 \mathrm{~mL}\left(37 \pm 1^{\circ} \mathrm{C}, 90 \mathrm{rpm}, 45\right.$ days) using orbital shaker (REMI CIS 24, India) to govern the biodegradability of untreated and thermally treated feedstock. Each bottle was fed with a mixture of FW and inoculum 
(with 1.2\% TS after dilution) corresponding to the final concentration of $1.5 \mathrm{~g} \mathrm{VS} \mathrm{L}^{-1}$ with initial $\mathrm{pH}$ between 7 and 7.3. Then, the upper space of each bottle was purged with nitrogen for at least $2 \mathrm{~min}$ and sealed by rubber plugs to guarantee anaerobic conditions. For each sample, the experiment was run in triplicate. Simultaneously, bottle containing inoculum alone was also made to measure the biogas generated from the inoculum. Initially the pressure (millibars) accumulated in bottle was measured by a pressure meter at the following time points: days $1,2,3,4,6,9,12,15,18,22,27,32$, and 45 , which was further used to calculate the volume of biogas produced in each bottle using the following ideal gas law equation:

$$
V_{\text {biogas }}=\frac{\left(P . V_{\text {head. }} C\right)}{R \cdot T}
$$

where $\mathrm{V}_{\text {Biogas }}$ is daily biogas volume (L),P is absolute pressure difference (mbar), $\mathrm{V}_{\text {Head }}$ is volume of the head space $(\mathrm{L}), \mathrm{C}$ is molar volume $\left(22.41 \mathrm{~mol}^{-1}\right), \mathrm{R}$ is universal gas constant $(83.14$ $\mathrm{L}$ mbar $\mathrm{K}^{-1} \mathrm{~mol}^{-1}$ ), $\mathrm{T}$ is absolute temperature (K).

Biogas yield was calculated by taking the average of the biogas produced per VS of added substrate in triplicate bottles. After the pressure measurement, each bottle was depressurized by penetrating the needle into the rubber cap. The reported experimental results demonstrate the mean of triplicate made for each sample. Reported biogas yields from the substrates were calculated by subtracting the biogas production of the inoculum from the gross biogas production of the substrates.

2.4. Data Fitting Using Models. To assess the performance parameter two models were used. The Modified Gompertz Equation (GM) (3) was used to analyse and describe the biogas production. This model was based on the direct relation between the biogas production and microbial activity during the occurrence of different phases of $\operatorname{AD}[15,22]$.

$$
C B P=B \exp \left\{-\exp \left[R_{b} e \frac{\alpha-t}{B}+1\right]\right\}
$$

where CBP is the cumulative biogas production ( $\mathrm{mL} / \mathrm{g} \mathrm{VS}$ ) at digestion time $\mathrm{t}$ days; $\mathrm{B}$ is biogas potential maximum production ( $\mathrm{mL} / \mathrm{g} \mathrm{VS}$ ); $\mathrm{R}_{\mathrm{b}}$ is maximum biogas production rate $(\mathrm{mL} / \mathrm{g} \mathrm{VS})$; e is $\exp (1)=2.718$; ' $\alpha$ ' is duration of lag phase (d).

Logistic function (LF) depends on the initial exponential increase that fits the global biogas production. This model assumes that the rate of biogas production is proportionate to the volume of gas already produced, the maximum production rate, and the maximum capacity of biogas production [23].

$$
C B P=\frac{B}{\left(1+\exp \left[4 R_{b}(\alpha-t) / B+2\right]\right)}
$$

Equation terms have same meaning as explained in (3).

Lag phase $(\alpha)$ is an important factor indicating the efficiency of biogas production, which was calculated in both the above equations $[24,25]$. The kinetic parameters of each of the batch bioreactors were estimated using nonlinear least square regression analysis (see (3) and (4)).
2.5. Energy Analysis. Energy content in the generated biogas was calculated on the basis of methane content available in the gas (average, 62\%), which was calculated using the ultimate analysis (Table 1) and Boyle's equation (5) [26]:

$$
\begin{aligned}
& \mathrm{C}_{\mathrm{c}} \mathrm{H}_{\mathrm{h}} \mathrm{O}_{\mathrm{o}} \mathrm{N}_{\mathrm{n}} \mathrm{S}_{\mathrm{s}}+\frac{1}{4}(4 \mathrm{c}-\mathrm{h}-2 \mathrm{o}+3 \mathrm{n}+2 \mathrm{~s}) \mathrm{H}_{2} \mathrm{O} \longrightarrow \\
& \frac{1}{8}(4 \mathrm{c}-\mathrm{h}+2 \mathrm{o}+3 \mathrm{n}+2 \mathrm{~s}) \mathrm{CO}_{2} \\
& \quad+\frac{1}{8}(4 \mathrm{c}+\mathrm{h}-2 \mathrm{o}-3 \mathrm{n}-2 \mathrm{~s}) \mathrm{CH}_{4}+\mathrm{nNH}_{3}+\mathrm{sH}_{2} \mathrm{~S}
\end{aligned}
$$

Then, initial VS based biogas volume $(\mathrm{mL})$ was multiplied by the lower heating value of methane $\left(33 \mathrm{~kJ} / \mathrm{L}\right.$ at $25^{\circ} \mathrm{C}$ and 1.01 bar). Heating load needed to keep the digester at particular temperature was not calculated because, during the practical application such as combined heat and power (CHP) systems, the system itself can typically meet the required load [20]. For the calculation of energy needed to heat the FW during pretreatment, (6) was used [20]:

\section{Energy input for material heating (KJ/}

$$
\mathrm{kg} \text { initial VS) }==m_{w} * C_{w} * \Delta t
$$

where $\mathrm{m}_{\mathrm{w}}$ is the mass of water required in $\mathrm{kg}$ per $\mathrm{kg}$ of VS of FW sample (367 kg/kg initial VS), $\mathrm{c}_{\mathrm{w}}$ is the specific heat of water $\left(4.2 \mathrm{~kJ} / \mathrm{kg} /{ }^{\circ} \mathrm{C}\right)$, and $\Delta \mathrm{t}$ is the increase in temperature $\left({ }^{\circ} \mathrm{C}\right.$, from $30^{\circ} \mathrm{C}$ to the required temperature).

Gain/loss in the biogas energy (kJ/kg initial VS) was then measured by subtracting the biogas energy from the energy given for the hot water pretreatment.

2.6. Analytical Methods. The TS and VS content of FW was determined according to the standard methods [27]. The $\mathrm{pH}$ value was measured by a $\mathrm{pH}$ meter (LMPH 10, Labman Scientific Instruments Pvt. Ltd., India). TCOD was measured by using the closed reflux method [28]. SCOD was analysed according to Finnish standard SFS 5504 [29]. The ultimate analysis was performed using the instrument model FLASH EA 1112 series (Thermo Finnigan, Italy). The soluble protein content was estimated by Lowry's method [30]. The Scanning electron microscopy (SEM) (Nova NanoSEM 450, Netherland) analysis was done to observe the microstructure and morphological difference between the untreated and treated samples of pulverised FW samples. Liquid samples were mounted on an aluminium stubs (10mm diameter) using double coated tape. A Fourier transform infrared (FTIR) spectrometer of spectrum 10.4.00 (PerkinElmer, USA) was employed to examine the chemical composition of untreated and treated FW samples.

2.7. Multicriteria Decision Making Model. Multicriteria decision making models (MCDM) are normally applied for both indefinite set of scenarios and definite set of scenarios. Pretreatment of FW is a definite set of scenarios having a definite set of output. For definite set of scenarios, there are many MCDM techniques such as ELECTRE (elimination et choix traduisant la realité), PROMETHEE (preference 
ranking organization method of enrichment evaluation), TOPSIS (technique for order preference by similarity to ideal solution), and VIKOR (VlseKriterijuska Optimizacija I Komoromisno Resenje) [31]. Several previous studies have applied VIKOR technique in the field of renewable and sustainable energy [32]. The steps involved in VIKOR method are described below.

Step 1. Create a decision matrix of alternative selected for experiment and output.

$$
D_{m n}=\left[\begin{array}{ccc}
x_{11} & x_{12} & x_{1 m} \\
x_{21} & \ldots & \ldots \\
x_{n 1} & \ldots & \ldots
\end{array}\right]
$$

Step 2. Create a normalized matrix using

$$
\rho_{i j}=\frac{x_{i j}}{\sum_{i=1}^{n} x_{i j}}
$$

Step 3. After creating normalized matrix, find entropy of each alternative

$$
E_{j}=-k \sum_{i=1}^{m} \rho_{i j} \ln \left(\rho_{i j}\right)
$$

where $\mathrm{k}=1 / \ln (\mathrm{m})$

Step 4. Calculate dispersion value of each alternative

$$
\pi_{j}=1-E_{j}
$$

Step 5. Find weight of each alternative

$$
\omega_{j}=\frac{\pi_{j}}{\sum_{j=1}^{n} \pi_{j}}
$$

Step 6. Determine utility measure $\left(\alpha_{i}\right)$ and regret measure $\left(\beta_{i}\right)$ using weights of each alternative

$$
\begin{aligned}
& \alpha_{i}=\sum_{j=1}^{n} \omega_{j} \frac{\left[x_{i j \max }-x_{i j}\right]}{\left[x_{i j \max }-x_{i j \min }\right]} \\
& \quad(\text { if } j \text { is benefit criteria) for } j=1,2 \ldots m \\
& \alpha_{i}=\sum_{j=1}^{n} \omega_{j} \frac{\left[x_{i j}-x_{i j \min }\right]}{\left[x_{i j \max }-x_{i j \min }\right]}
\end{aligned}
$$

(if $j$ is cost criteria) for $j=1,2 \ldots m$,

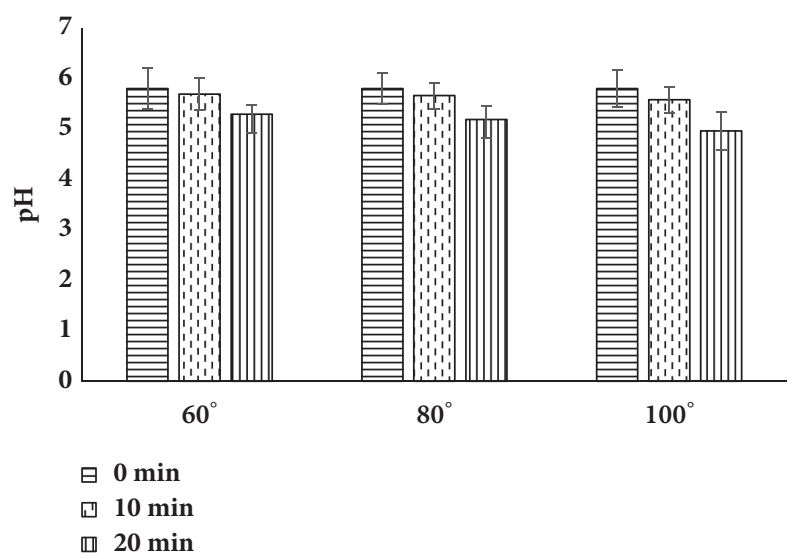

FIGURE 2: Variation in $\mathrm{pH}$ after thermal pretreatment of hotel food waste (two-factor ANOVA of data set showed $p=0.001662$ ).

$$
\begin{aligned}
\beta_{i}=\max \text { of }\left\{\omega_{j} \frac{\left[x_{i j}-x_{i j m i n}\right]}{\left[x_{i j m a x}-x_{i j m i n}\right]}\right\} \\
\text { for } j=1,2, \ldots m
\end{aligned}
$$

from decision matrix; obtain maximum $\left(x_{i j m a x}\right)$ and minimum $\left(x_{i j m i n}\right)$ value for each output.

Step 7. Finally calculate VIKOR index, $\Omega_{i}$

$$
\Omega_{i}=\varepsilon\left(\frac{\alpha_{i}-\alpha_{i}^{-}}{\alpha_{i}^{+}-\alpha_{i}^{-}}\right)+(1-\varepsilon)\left(\frac{\beta_{i}-\beta_{i}^{-}}{\beta_{i}^{+}-\beta_{i}^{-}}\right)
$$

where $\alpha_{i}^{+}$and $\beta_{i}^{+}=\max$ of $\alpha_{i}$ and $\beta(i=1,2, \ldots . m)$ and $\alpha_{i}^{-}$and $\beta_{i}^{-}=\min$ of $\alpha_{i}$ and $\beta(i=1,2, \ldots . . m)$.

$\varepsilon$ is introduced as weight for the maximum value of utility and $(1-\varepsilon)$ is the weight of the individual regret and normally its value of $\varepsilon$ is taken as 0.5 .

2.8. Statistical Analysis. All the data were tested for the level of significance and analysis of variance (ANOVA; $\mathrm{p}<0.05$ ) was performed in Microsoft excel spreadsheet (version 2016) using solver function.

\section{Results and Discussion}

\subsection{Effects of Thermal Pretreatment on Degradation of FW}

3.1.1. $p H$. Figure 2 shows the effect of pretreatment temperature and duration time on the $\mathrm{pH}$ of $\mathrm{FW}$. The untreated sample was mild acidic in nature ( $\mathrm{pH}$ 5.8). A significant decrement in the $\mathrm{pH}$ was observed following the thermal pretreatment of FW. The increase in pretreatment temperature from $60^{\circ}$ to $100^{\circ} \mathrm{C}$ led to drop in $\mathrm{pH}$. The duration of pretreatment further decreased the $\mathrm{pH}$ (Figure 2). There is strong dependence of $\mathrm{pH}$ decrease on severity factor values $\left(\mathrm{R}^{2}=0.98\right.$ in quadratic regression and 0.71 in linear regression) also (Table 2) that may be due to release of the sugars followed by pretreatment.

Thus, progressive increase in pretreatment severity resulted into decrease in $\mathrm{pH}$, which may be due to the phase 


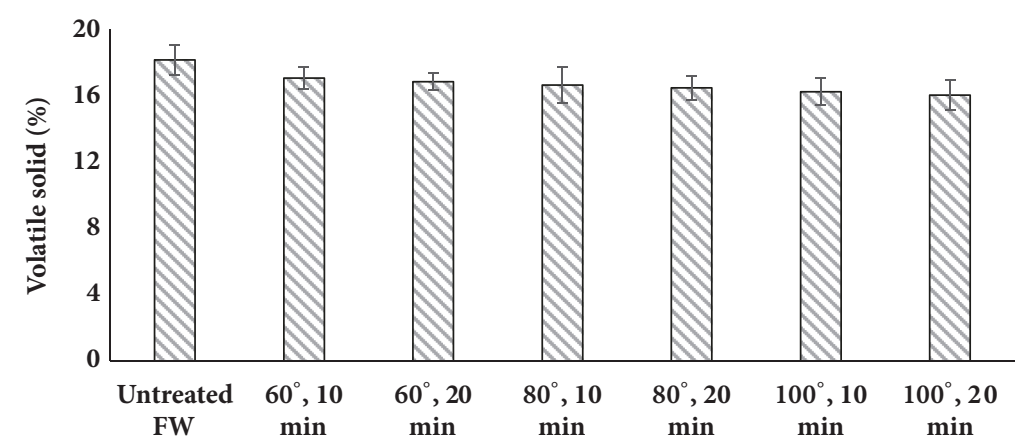

FIGURE 3: Volatile solid proportion after thermal pretreatment in hotel food waste (two-factor ANOVA of data set showed $\mathrm{p}=0.000025$ ).

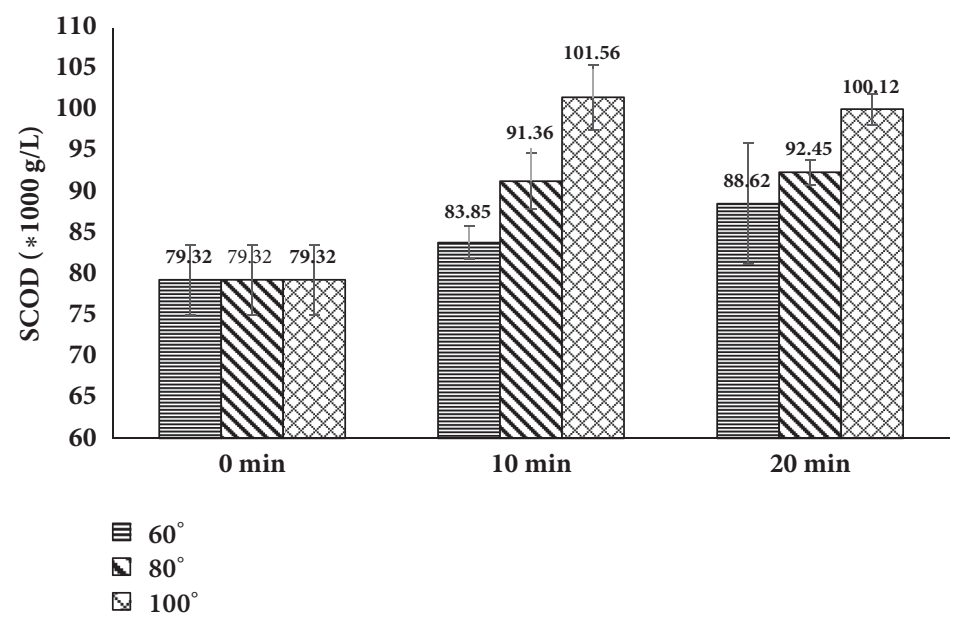

FIGURE 4: Effect of pretreatment on SCOD content of hotel food waste (two-factor ANOVA of data set showed $\mathrm{p}=0.03$ ).

change of organic acids from solid to liquid in the FW. Other reasons could be the thermal hydrolysis reaction, i.e., highpressure boiling of waste followed by rapid decompression, which leads to the reduction in $\mathrm{pH}$. This process increases the biodegradability of waste along with reduction in the microbial load to an extent depending on temperatures and time.

3.1.2. VS. The VS content for the untreated FW was 18.18 $\pm 1.33 \%$. It can be concluded that, as pretreatment severity increases, no notable decrease in the VS content of the substrates was observed (Figure 3 ). The negligible decrease in VS may be attributed to the high temperatures entailing the loss of volatile substances and thus the decline in final VS content [33].

3.1.3. SCOD. It is a parameter, which can be used as a performance indicator of digestion process in $\mathrm{AD}$. It reflects the amount of soluble organic matter present in the substrates in the form of dissolved organic matter. Figure 4 depicts SCOD for untreated and pretreated FW. For pretreatment temperatures $\left(60,80\right.$, and $\left.100^{\circ} \mathrm{C}\right)$, the observed increase in the SCOD content was marginally significant and the values were about to get stable after $10 \mathrm{~min}$. The maximum solubilization was observed at $100^{\circ} \mathrm{C}, 10 \mathrm{~min}$ which was around $28 \%$, while it was around 16 and $11 \%$ for pretreatments performed at 80 and $60^{\circ} \mathrm{C}$ for $20 \mathrm{~min}$, respectively.

The obvious reason for the increased SCOD content on increasing the pretreatment temperature and duration is the breakage of chemical bonds, including VFA's, polysaccharides, and proteins, by providing external energy in form of heat [33].

The results above support the liquid hot water pretreatment as the preferred choice for enhancing the digestion of FW. Kondusamy et al. [34] also observed the improvement in biogas generation from liquid hot water pretreated FW. Furthermore, it may also increase the production of digestate/slurry due to the transformation of organics in FW from solid to liquid.

3.1.4. Soluble Protein. Figure 5 illustrates the solubilization of FW protein after pretreatment. The pretreatment was observed to affect the protein content of FW in a similar trend as the COD solubilization. The protein solubilization increased linearly with temperature (Figure 5). The highest protein solubilization of around $16 \%$ was obtained at pretreatment condition of $100^{\circ} \mathrm{C}$ and $20 \mathrm{~min}$.

3.1.5. Effects of Pretreatment on FW Functional Groups. FTIR analysis was performed in the range of $4000-400 \mathrm{~cm}^{-1}$ 


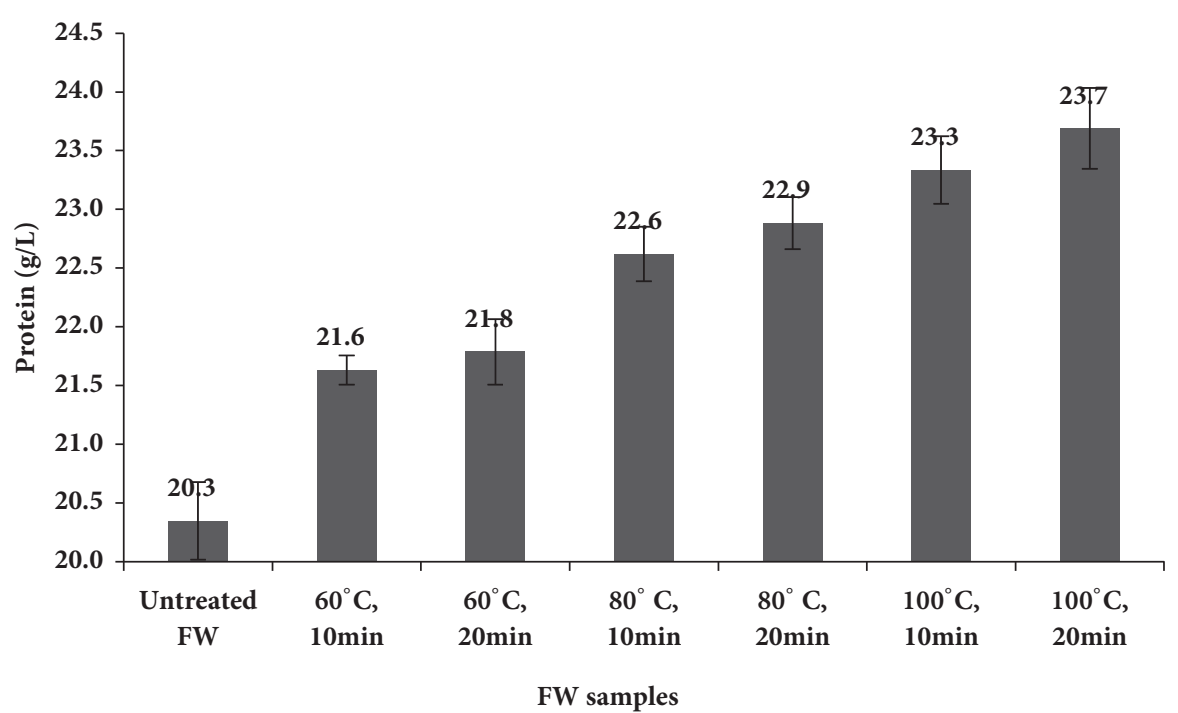

FIGURE 5: Protein solubilization in hotel food waste (two-factor ANOVA of data set showed $\mathrm{p}=0.0000009$ ).

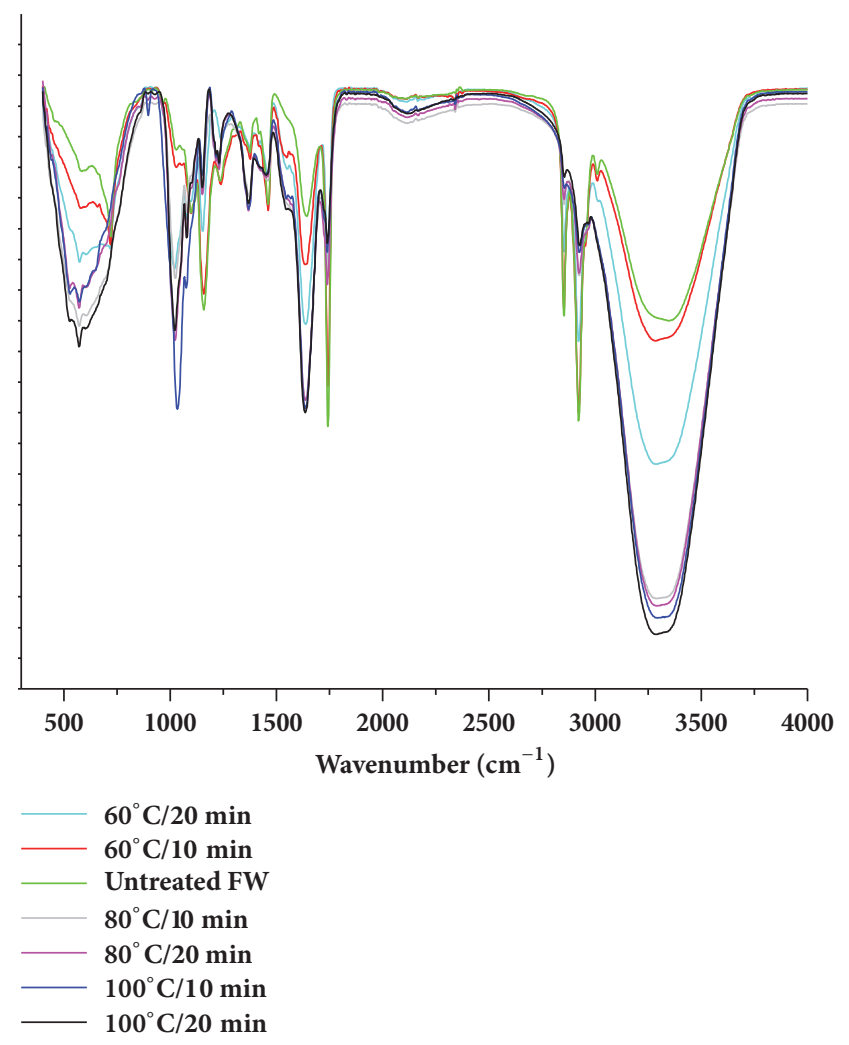

FIGURE 6: FTIR spectra of thermally pretreated hotel food waste.

to characterise the effect of pretreatment on the functional groups and the chemical structure of untreated and pretreated FW (Figure 6). The peak within the range of 3000 to $3600 \mathrm{~cm}^{-1}$ showed the combined presence of $-\mathrm{OH}$ group from the internal water and $\mathrm{N}-\mathrm{H}$ group from the amide I of FW. The peak intensity was observed to increase with pretreatment severity because of solubilization of complex insoluble organics to simpler soluble organics. However, above $80^{\circ} \mathrm{C}$, the increment in the $-\mathrm{OH}$ stretching vibrations did not remain significant. At wavelengths 1655 and 1545 $\mathrm{cm}^{-1}$, peaks of $\mathrm{C}=\mathrm{O}$ and $\mathrm{C}-\mathrm{N}$ stretching vibrations of amide I and II of protein were observed $[35,36]$. Since degradation of protein occurred during the pretreatment, peaks of amino acids or smaller fragments of carboxyl group and $\mathrm{NH}_{3}$ become wider with temperature and duration. No significant change was detected in the other functional groups for the analysed samples.

3.1.6. Scanning Electron Microscopy (SEM). SEM assists to understand the effect of thermal pretreatment on the microstructural properties of FW. Clusters of varying sizes and shapes were observed in the scanning electron micrographs, which were the composites of carbohydrates, proteins, and lipids (main organic compounds in FW). In contrast to treated FW, untreated FW contains more compact and cemented particles, which possess flat, rigid, and smooth surfaces of size ranging between 30 and $50 \mu \mathrm{m}$ (Figure 7(a)). Figures 7(b), 7(c), and 7(d) illustrated the disruption of bigger particles into smaller rugged, rough, and serrated surface particles of sizes 10-30 $\mu \mathrm{m}$ following pretreatment.

Therefore, it can be concluded that liquid hot water pretreatment resulted into decrystallisation of FW that would, in turn, be helpful in enhancing the contact between substrates and microorganisms via enhancing the available surface area for increased biogas production.

3.2. Biogas Yield and Production Rate. The improvement of cumulative biogas production from untreated and thermally pretreated FW is shown in Figure 8. As the experiment was executed, the biogas production started instantly on the first day of digestion, and primary lag phase was barely observed in pretreated samples, in contrast to untreated FW, which may be due to the less solublised organic content of FW. The production of biogas from FW was significantly increased by the thermal pretreatment under all conditions. The maximum biogas yield of $783 \mathrm{~mL} / \mathrm{g}$ VS was attained by 


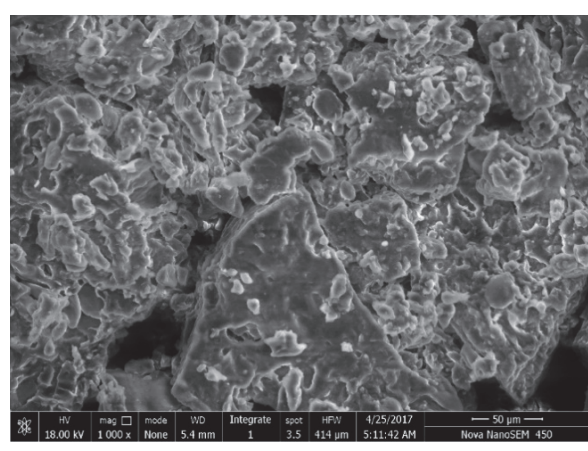

(a)

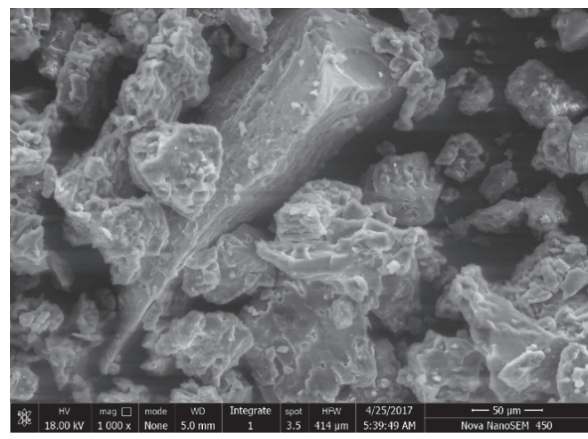

(c)

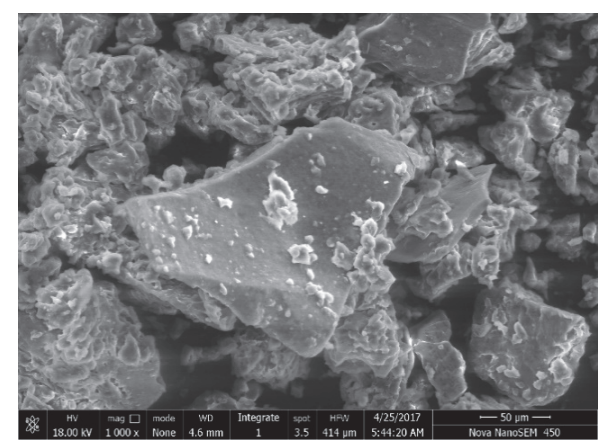

(b)

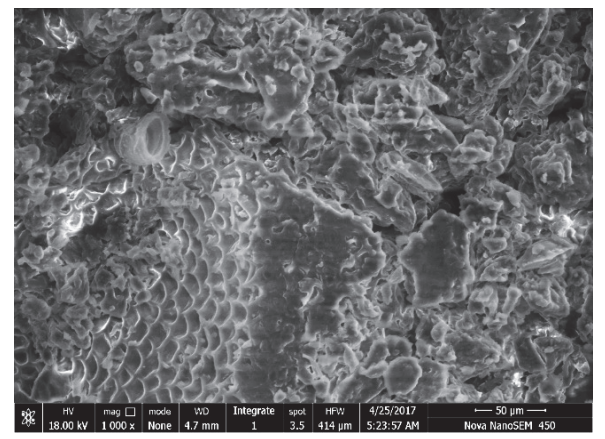

(d)

FIGURE 7: SEM images of FW under magnification of 1000x. (a) Untreated FW, (b) $60^{\circ}, 10 \mathrm{~min}$, (c) $80^{\circ}, 10 \mathrm{~min}$, and (d) $100^{\circ}, 10 \mathrm{~min}$.

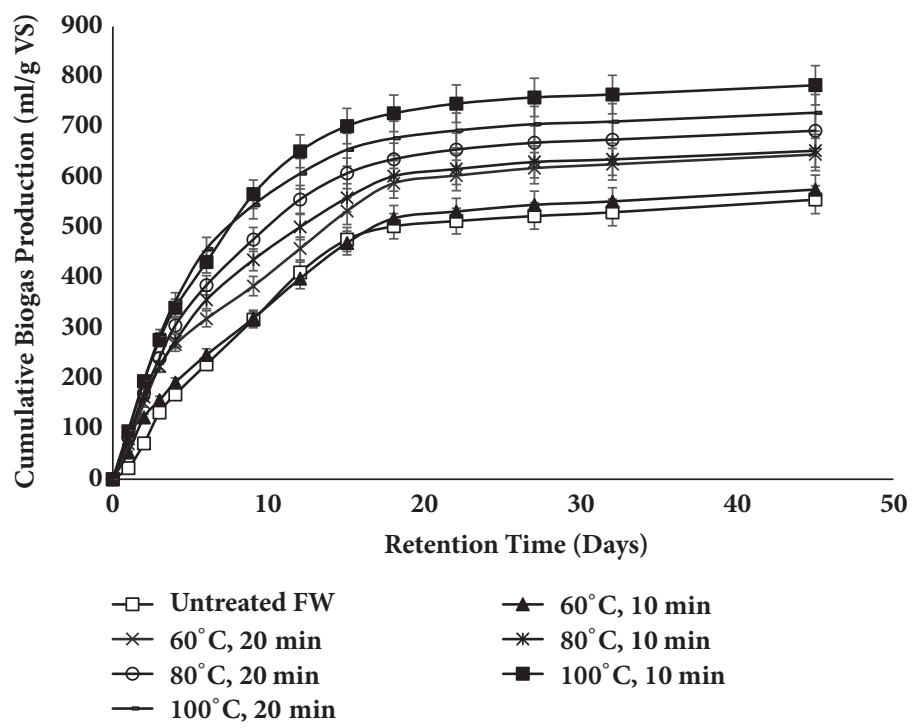

FIGURE 8: Cumulative biogas production from untreated and thermally pretreated hotel food waste (two-factor ANOVA of data set showed $\mathrm{p}=1.00647 \mathrm{E}-29)$.

the treatment temperature at $100^{\circ} \mathrm{C}, 10 \mathrm{~min}$. It showed the impact of moderate temperature pretreatment on augmenting the degradation of FW which was supported by the SCOD findings. Similar biogas production patterns were reported by Li et al. [24]. The negligible lag phase can be identified based on the rapid hydrolysis of solubilized compounds and quick adaptability of the microbes for the substrate [25].
The other curves at temperatures $60^{\circ}$ and $80^{\circ} \mathrm{C}$ with treatment durations 10 and $20 \mathrm{~min}$, respectively, demonstrated analogous trend due to linear increase in the SCOD and protein content, though the biogas production observed was less than the yield attained at $100^{\circ} \mathrm{C}, 10 \mathrm{~min}$.

The development of refractory inhibitory compounds such as melanoidin and increase in concentration of soluble phenol at higher thermal pretreatment temperature 
TABLE 3: Results of kinetic study-modified Gompertz model and Logistic model.

\begin{tabular}{|c|c|c|c|c|c|c|c|}
\hline Parameter & $\begin{array}{c}\text { Untreated } \\
\text { FW }\end{array}$ & $60^{\circ} \mathrm{C}, 10 \mathrm{~min}$ & $\begin{array}{l}60^{\circ} \mathrm{C}, \\
20 \mathrm{~min}\end{array}$ & $\begin{array}{l}80^{\circ} \mathrm{C}, \\
10 \mathrm{~min} \\
\end{array}$ & $\begin{array}{l}80^{\circ} \mathrm{C}, \\
20 \mathrm{~min}\end{array}$ & $\begin{array}{l}100^{\circ} \mathrm{C}, \\
10 \mathrm{~min}\end{array}$ & $\begin{array}{l}100^{\circ} \mathrm{C}, \\
20 \mathrm{~min}\end{array}$ \\
\hline $\begin{array}{l}\text { Cumulative biogas } \\
\text { production-experimental } *\end{array}$ & 410 & 398 & 458 & 501 & 556 & 652 & 607 \\
\hline \multicolumn{8}{|l|}{ Modified Gompertz } \\
\hline $\begin{array}{l}\text { Cumulative biogas } \\
\text { production-predicted } *\end{array}$ & 410.31 & 396.98 & 452.10 & 482.45 & 541.98 & 627.64 & 553.22 \\
\hline Lag phase (days) & 0.5 & 0.06 & 0.05 & 0.03 & 0.02 & 0.01 & 0 \\
\hline $\mathrm{R}^{2}$ & 0.9909 & 0.9666 & 0.9528 & 0.9733 & 0.9837 & 0.978 & 0.9837 \\
\hline RMSE (\%) & 5.95 & 2.95 & 2.07 & 2.34 & 2.56 & 2.02 & 1.97 \\
\hline \multicolumn{8}{|l|}{ Logistic Model } \\
\hline $\begin{array}{l}\text { Cumulative biogas } \\
\text { production-predicted } *\end{array}$ & 410.93 & 398.49 & 457.04 & 494.61 & 551.86 & 643.16 & 577.48 \\
\hline Lag phase (days) & 0 & 0 & 0 & 0 & 0 & 0 & 0 \\
\hline $\mathrm{R}^{2}$ & 0.9937 & 0.9698 & 0.9573 & 0.9757 & 0.9875 & 0.9814 & 0.9852 \\
\hline RMSE (\%) & 6.73 & 14.1 & 15.54 & 12.42 & 9.58 & 11.25 & 10.8 \\
\hline
\end{tabular}

$*$ Value was taken until $12^{\text {th }}$ day.

and duration $\left(100^{\circ} \mathrm{C}, 20 \mathrm{~min}\right)$ may reduce the activity of methanogens but not utterly after witnessing the high biogas yield compared to untreated FW [33].

The whole process of $\mathrm{AD}$ indicated the rapid degradation of feedstock and rather intensive biogas production [24, 37]. Readily available soluble organic compounds in untreated or pretreated FW resulted in rapid biogas production in initial phase of AD. Thus, higher severity was considered as the sole reason to provide higher digestible organics in pretreated FW, compared to the moderately degradable compounds in untreated food waste. The reason behind the sudden decrease in the production rate after the first week is the accretion of VFA's, due to the rapid growth of acidogens in comparison to methanogens, which timely consume VFA's to produce biogas. In turn acidogens increase, leading to reduction in $\mathrm{pH}$ out of the optimum range for AD.

Thus, the thermal pretreatment highlights the rapid solubilization of organic and inorganic macromolecules. Moreover, organic compounds with low molecular weight and increased surface area promote the contact between the microbes and substrate [38], resulting in increased conversion of organic materials to biogas.

3.3. Kinetic Study. The expected kinetic parameters based on Gompertz and Logistic functions models are shown in Table 3. Parameters such as estimated biogas yield and lag phase duration were also calculated using the equations of the two models. For the validation purpose, the trend lines for experimental cumulative biogas values were plotted against the expected values till $12^{\text {th }}$ day, as the biogas production curve remained steep.

These two models (Gompertz and Logistic model) were also used by group of researchers ([25, 39]; Pariosh et al., 2017) to fit the experimental biogas production curve against the predictions. The relation between the two curves was evaluated on the basis of adjusted R-square and Root mean square error (RMSE).
Biogas production potential of the untreated and treated FW at temperatures $60^{\circ}, 80^{\circ}$ and $100^{\circ} \mathrm{C}$ (each for 10,20 min) were measured to be $555,575,645,653,692,783$ and $728 \mathrm{~mL} / \mathrm{g}$ VS. Based on final $\mathrm{CH}_{4}$ content (average 62\%) the methane content were 344, 357, 400, 405, 429, 485 and $451 \mathrm{~mL} / \mathrm{g}$ VS respectively. The maximum biogas yield was obtained with the pretreatment temperature and duration of $100^{\circ} \mathrm{C}, 10 \mathrm{~min}$. Lag time, RMSE and $\mathrm{R}^{2}$ values for both the models, at each operating temperature, are shown in Table 3.

Calculated lag time for both the kinetic models was found to be nearly zero for every case because of the presence of active bacteria in the added inoculum and readily accessible biodegradable component in the FW. It also signifies the rapid consumption of soluble material by anaerobic biomass [25]. The $\mathrm{R}^{2}$ values for Gompertz and Logistic model are quite similar (as shown in Table 3 ) and fall within the range of 0.98-0.99 that ensures the fitting of predicted values to the experimental values. Whereas, The RMSE (\%) values for Gompertz model are lower than that of logistic model (between 2-6\%), which favours the former model more than the later for the kinetic study of biogas production.

3.4. Net Energy Production Analysis. Untreated FW can generate $12.89 \mathrm{MJ} / \mathrm{kg}$ (VS basis) of energy via $\mathrm{AD}$. It was expected that pretreatment can improve the net benefit by increasing the biogas yield. However, pretreatment can cause dry matter loss and requires additional energy, which can offset the improvement in biogas yield. As shown in Table 4, the energy outputs of LHW pretreated FW (13.35-18.16 MJ/kg initial VS) are greater than that of untreated FW $(12.89 \mathrm{MJ} / \mathrm{kg}$ initial VS) due to the enhancement of the solubilization of organic compounds during LHW pretreatment. Moreover, LHW pretreatment requires (46.05-107.48) MJ/kg initial VS for heating up the feedstock, resulting in negative net biogas energy (Table 4). Therefore, LHW pretreatment under the studied conditions is looking less promising but it is suggested 
TABle 4: Net benefit of energy production from biogas due to the thermal pretreatment of FW.

\begin{tabular}{lcccc}
\hline Pretreatment conditions & Severity factor & $\begin{array}{c}\text { Total biomass } \\
\text { energy } \\
\text { production } \\
(\mathbf{M J} / \mathbf{k g ~ V S})\end{array}$ & $\begin{array}{c}\text { Energy given } \\
\text { for the } \\
\text { pretreatment } \\
\text { (MJ/kg VS) }\end{array}$ & $\begin{array}{c}\text { Net biogas } \\
\text { energy } \\
\text { production } \\
(\mathbf{M J} / \mathbf{k g ~ V S})\end{array}$ \\
\hline $60^{\circ}, 10 \mathrm{~min}$ & 1.7 & 13.35 & 46.06 & $\mathrm{Negative}$ \\
$80^{\circ}, 10 \mathrm{~min}$ & 2.3 & 15.15 & 76.66 & $\mathrm{Negative}$ \\
$100^{\circ}, 10 \mathrm{~min}$ & 2.9 & 18.16 & 107.46 & $\mathrm{Negative}$ \\
Untreated FW & 0 & 12.89 & 0 & 12.89 \\
\hline
\end{tabular}

TABLE 5: Decision matrix as per experimental results of thermal pretreatment of FW.

\begin{tabular}{|c|c|c|c|c|c|}
\hline Alternatives & $\mathrm{pH}\left(\mathrm{C}_{1}\right)$ & $\begin{array}{c}\text { VS reduction } \\
(\%)\left(\mathrm{C}_{2}\right)\end{array}$ & $\begin{array}{c}\text { sCOD } \\
(\mathrm{g} / \mathrm{L})\left(\mathrm{C}_{3}\right)\end{array}$ & $\begin{array}{c}\text { Soluble protein } \\
(\mathrm{g} / \mathrm{L})\left(\mathrm{C}_{4}\right)\end{array}$ & $\begin{array}{c}\text { Biogas yield } \\
(\mathrm{mL} / \mathrm{g} \text { VS })\left(\mathrm{C}_{5}\right)\end{array}$ \\
\hline $60^{\circ} \mathrm{C}, 10$ minutes $\left(\mathrm{A}_{1}\right)$ & 5.69 & 17.09 & 83.85 & 21.6 & 575.66 \\
\hline $60^{\circ} \mathrm{C}, 20$ minutes $\left(\mathrm{A}_{2}\right)$ & 5.29 & 16.87 & 88.62 & 21.8 & 645.73 \\
\hline $80^{\circ} \mathrm{C}, 10$ minutes $\left(\mathrm{A}_{3}\right)$ & 5.66 & 16.66 & 91.36 & 22.6 & 653.24 \\
\hline $80^{\circ} \mathrm{C}, 20$ minutes $\left(\mathrm{A}_{4}\right)$ & 5.19 & 16.49 & 92.45 & 22.9 & 692.68 \\
\hline $100^{\circ} \mathrm{C}, 10$ minutes $\left(\mathrm{A}_{5}\right)$ & 5.58 & 16.26 & 101.56 & 23.3 & 783.23 \\
\hline $100^{\circ} \mathrm{C}, 20$ minutes $\left(\mathrm{A}_{6}\right)$ & 4.96 & 16.09 & 100.12 & 23.7 & 728.48 \\
\hline Sum & 32.37 & 99.46 & 557.96 & 135.9 & 4079.02 \\
\hline Max & 5.69 & 17.09 & 101.56 & 23.7 & 783.23 \\
\hline Min & 4.96 & 16.09 & 83.85 & 21.6 & 575.66 \\
\hline Max-min & 0.73 & 1 & 17.71 & 2.1 & 207.57 \\
\hline
\end{tabular}

TABLE 6: Normalized matrix is obtained as below for each alternative, criterion using (8).

\begin{tabular}{lccccc}
\hline & $\mathrm{C}_{1}$ & $\mathrm{C}_{2}$ & $\mathrm{C}_{3}$ & $\mathrm{C}_{4}$ & $\mathrm{C}_{5}$ \\
\hline $\mathrm{A}_{1}$ & 0.175780043 & 0.171827871 & 0.15027959 & 0.158940397 & 0.141127035 \\
$\mathrm{~A}_{2}$ & 0.163422922 & 0.169615926 & 0.15882859 & 0.160412068 & 0.158305181 \\
$\mathrm{~A}_{3}$ & 0.174853259 & 0.167504524 & 0.163739336 & 0.166298749 & 0.16014631 \\
$\mathrm{~A}_{4}$ & 0.160333642 & 0.165795295 & 0.165692881 & 0.168506255 & 0.169815299 \\
$\mathrm{~A}_{5}$ & 0.172381835 & 0.163482807 & 0.182020217 & 0.171449595 & 0.192014258 \\
$\mathrm{~A}_{6}$ & 0.153228298 & 0.161773577 & 0.179439386 & 0.174392936 & 0.178591917 \\
\hline
\end{tabular}

that the residual heat of the CHP may be used to pretreat the FW and then followed by biogas production.

3.5. Multicriteria Decision Making Modelling. After the analysis was perfomed and lots of data were genrated; for multicriteria analysis of thermal pretreatment of FW, a set of output data was selected for employing VIKOR method. A set of possible alternatives based on number of tretament temperature and time duration was prepared for getting best tretament condition (Table 5). Six different alternatives such as 60,80 and $100^{\circ} \mathrm{C}$ pretreatment for 10 and 20 minutes were arranged in a matrix against effect on $\mathrm{pH}, \mathrm{VS}$, SCOD, soluble protein and biogas yield after thermal pretreatment of FW.

In Table 5, each set of data have different unit. Making each data dimensionless is prior requirement before applying MCDM methodological approach and making the data uniform for comparison. To make each output dimensionless, normalized matrix was created using equation (8) (Table 6).
After making each entry of the data set dimensionless, entropy value, dispersion value and weight of each alternative was determined (Table 7) using equations (9), (10) and (11).

After getting the values of entropy, dispersion and weight, utility measures, regret measure and VIKOR index were calculated (Table 8) using equations (11), (13), (14) and (15).

Finally, rank of alternatives were provided as per VIKOR index obtained in ascending order, and best alternative is one having minimum value of VIKOR index (Table 9).

The obtained rank showed the effect of pretreatment and time duration on various factors tabulated in Table 5. Alternatives $A_{5}$ and $A_{6}$ obtined first and second best rank for thermal pretreatment of FW. However, time duration may play a vital role despite having same temperature for pretreatment, alternative $A_{6}$ got second rank because of pretreatment time (20 minutes). Alternative $A_{1}, A_{2}, A_{3}$ and $\mathrm{A}_{4}$ secured sixth, fifth, fourth and third rank respectively as per VIKOR approach. This clearly showed that as temperature is reduced for pretreatment, overall performance of reactor 
TABLE 7: Determining the value of entropy, dispersion, and weight of each alternative using (9), (10), and (11).

\begin{tabular}{lccc}
\hline Alternatives & Entropy, $\boldsymbol{E}_{\boldsymbol{j}}$ & Dispersion, $\boldsymbol{\pi}_{\boldsymbol{j}}$ & Weight, $\boldsymbol{\omega}_{\boldsymbol{j}}$ \\
\hline $\mathrm{A}_{1}$ & 0.999302322 & 0.1842 & 0.18328732 \\
$\mathrm{~A}_{2}$ & 0.999302322 & 0.177041 & 0.176163955 \\
$\mathrm{~A}_{3}$ & 0.999302322 & 0.167215 & 0.166386118 \\
$\mathrm{~A}_{4}$ & 0.999302322 & 0.168169 & 0.167336036 \\
$\mathrm{~A}_{5}$ & 0.999302322 & 0.146966 & 0.146238199 \\
$\mathrm{~A}_{6}$ & 0.999302322 & 0.161388 & 0.160588372 \\
\hline
\end{tabular}

TABLE 8: Utility measure $\left(\alpha_{i}\right)$, regret measure $\left(\beta_{i}\right)$, and VIKOR index $\left(\Omega_{i}\right)$ for each alternative and criterion using (12), (13), (14), and (15).

\begin{tabular}{ccccccccc}
\hline & $\mathrm{C}_{1}$ & $\mathrm{C}_{2}$ & $\mathrm{C}_{3}$ & $\mathrm{C}_{4}$ & $\mathrm{C}_{5}$ & $\boldsymbol{\alpha}_{\boldsymbol{i}}$ & $\boldsymbol{\beta}_{\boldsymbol{i}}$ \\
\hline $\mathrm{A}_{1}$ & 0 & 0 & 0.248051576 & 0.062278006 & 0.525738008 & 0.83606759 & 0.525738008 & 1 \\
$\mathrm{~A}_{2}$ & 0.076771049 & 0.005241554 & 0.181241524 & 0.056346768 & 0.348263122 & 0.667864016 & 0.348263122 & 0.716785979 \\
$\mathrm{~A}_{3}$ & 0.005757829 & 0.010244856 & 0.142864262 & 0.032621813 & 0.329241623 & 0.520730382 & 0.329241623 & 0.604021944 \\
$\mathrm{~A}_{4}$ & 0.095963811 & 0.014295148 & 0.127597394 & 0.023724955 & 0.229347096 & 0.490928403 & 0.229347096 & 0.486020253 \\
$\mathrm{~A}_{5}$ & 0.021112038 & 0.019774954 & 0 & 0.011862477 & 0 & 0.05274947 & 0.021112038 & 0 \\
$\mathrm{~A}_{6}$ & 0.140107164 & 0.023825246 & 0.020169072 & 0 & 0.138672043 & 0.322773525 & 0.140107164 & 0.290263409 \\
\hline
\end{tabular}

TABLE 9: Rank of alternatives.

\begin{tabular}{lcc}
\hline Alternatives & VIKOR index & Rank \\
\hline $60^{\circ} \mathrm{C}, 10$ minutes $\left(\mathrm{A}_{1}\right)$ & 1 & 6 \\
$60^{\circ} \mathrm{C}, 20$ minutes $\left(\mathrm{A}_{2}\right)$ & 0.716785979 & 5 \\
$80^{\circ} \mathrm{C}, 10$ minutes $\left(\mathrm{A}_{3}\right)$ & 0.604021944 & 4 \\
$80^{\circ} \mathrm{C}, 20$ minutes $\left(\mathrm{A}_{4}\right)$ & 0.486020253 & 3 \\
$100^{\circ} \mathrm{C}, 10$ minutes $\left(\mathrm{A}_{5}\right)$ & 0 & 1 \\
$100^{\circ} \mathrm{C}, 20$ minutes $\left(\mathrm{A}_{6}\right)$ & 0.290263409 & 2 \\
\hline
\end{tabular}

is also decreases. Further, the experimental results were in agreement with the rank provided by the VIKOR MCDM approach.

According to MCDM using VIKOR technique, pretreatment of $\mathrm{FW}$ at $100^{\circ} \mathrm{C}, 10 \mathrm{~min}$ was observed to be the best treatment condition among others and also experimentally this alternative helps to achieve maximum biogas yield (783 $\mathrm{ml} / \mathrm{g} \mathrm{VS})$.

\section{Conclusions}

Thermal energy was employed for FW pretreatment concerning augmentation of biogas yield in the $\mathrm{AD}$ process. A significant enhancement of organic matter solubilization and biogas production from FW was observed after thermal pretreatment. A direct correlation between soluble COD, soluble protein and biogas production was observed. However, the soluble COD did not increase after the temperature and duration of $\left(100^{\circ} \mathrm{C}\right.$ and $\left.10 \mathrm{~min}\right)$. Thermal pretreatment enhances the degradation of organic and inorganic compounds, which leads to efficient $\mathrm{AD}$ of FW treated at high temperature and longer duration. SEM analysis showed that the thermal pretreatment disrupts and reduces the size of the food particles and increases the roughness to promote the contact between the substrate and microbes. Whereas, FTIR also showed the presence of carbohydrates, proteins and lipids as well as their conversion in to simpler forms with the increasing severity of pretreatment. Both kinetics models (Modified Gompertz and Logistic function) showed agreement with the experimental curve and fit up to the similar extent with $\mathrm{R}^{2}$ value greater than $95 \%$. Net energy analysis showed that thermal pretreatment was not an economical method of pretreatment as it incurs more energy as input than additional output energy from biogas. Therefore, in the present form it may have less feasibility; however employment of residual CHP heat for FW pretreatment may lead to development of an energy efficient, sustainable, and economic process.

\section{Disclosure}

The authors alone are responsible for the content and writing of the paper.

\section{Conflicts of Interest}

The authors declare that they have no conflicts of interest.

\section{Acknowledgments}

Paras Gandhi and Kunwar Paritosh acknowledge fellowships from Malaviya National Institute of Technology Jaipur 
and facilities at Centre for Energy and Environment, Malaviya National Institute of Technology, Jaipur India. Javier Lizasoain and Andreas Gronauer thank Department of Sustainable Agricultural Systems, University of Natural Resources and Life Sciences, Vienna, Austria, for facilities. Vivekanand Vivekanand and Alexander Bauer are thankful to Department of Science and Technology (Grant no. INT/AUSTRIA/BMWF/P-01/2017) Government of India and WTZ-BMWF Austria for financial support, respectively.

\section{References}

[1] K. Paritosh, S. K. Kushwaha, M. Yadav, N. Pareek, A. Chawade, and V. Vivekanand, "Food Waste to Energy: An Overview of Sustainable Approaches for Food Waste Management and Nutrient Recycling," BioMed Research International, vol. 2017, 2017.

[2] K. Paritosh, S. Mathur, N. Pareek, and V. Vivekanand, "Feasibility study of waste (d) potential: co-digestion of organic wastes, synergistic effect and kinetics of biogas production," International Journal of Environmental Science and Technology, vol. 15, no. 5, pp. 1009-1018, 2018.

[3] A. Makhija, "Control Food Wastage, Reduce Malnutrition," Multidisciplinary Scientific Reviewer, vol. 2, no. 5, pp. 12-14, 2015, http://oiirj.org/msr/may2015/02.pdf.

[4] India Tourism Statistics at a glance, "Ministry of Tourism, Government of India," 2013, http://ficci.in/spdocument/20610/ Report-Tourism-Infrastructure.pdf.

[5] R. Chedwal, J. Mathur, G. D. Agarwal, and S. Dhaka, "Energy saving potential through Energy Conservation Building Code and advance energy efficiency measures in hotel buildings of Jaipur City, India," Energy and Buildings, vol. 92, pp. 282-295, 2015.

[6] N. Ramzan, S. Naveed, N. Latif, and A. R. Saleemi, "Characterization of Kitchen waste as a Feedstock for Biogas Generation by Thermophilic Anaerobic," Digestion.-NUST Journal of Engineering and Sciences, vol. 3, pp. 15-21, 2010.

[7] G. Di Girolamo, L. Bertin, L. Capecchi, C. Ciavatta, and L. Barbanti, "Mild alkaline pre-treatments loosen fibre structure enhancing methane production from biomass crops and residues," Biomass \& Bioenergy, vol. 71, pp. 318-329, 2014.

[8] C. Wan and Y. Li, "Effect of hot water extraction and liquid hot water pretreatment on the fungal degradation of biomass feedstocks," Bioresource Technology, vol. 102, no. 20, pp. 97889793, 2011.

[9] W. Kuo and K. Cheng, "Use of respirometer in evaluation of process and toxicity of thermophilic anaerobic digestion for treating kitchen waste," Bioresource Technology, vol. 98, no. 9, pp. 1805-1811, 2007.

[10] J. Ariunbaatar, A. Panico, D. H. Yeh, F. Pirozzi, P. N. L. Lens, and G. Esposito, "Enhanced mesophilic anaerobic digestion of food waste by thermal pretreatment: Substrate versus digestate heating," Waste Management, vol. 46, pp. 176-181, 2015.

[11] J. Ma, T. H. Duong, M. Smits, W. Verstraete, and M. Carballa, "Enhanced biomethanation of kitchen waste by different pretreatments," Bioresource Technology, vol. 102, no. 2, pp. 592-599, 2011.

[12] Y. Li, Y. Jin, J. Li, H. Li, Z. Yu, and Y. Nie, "Effects of thermal pretreatment on degradation kinetics of organics during kitchen waste anaerobic digestion," Energy, vol. 118, pp. 377-386, 2017.
[13] C. Zhang, H. Su, J. Baeyens, and T. Tan, "Reviewing the anaerobic digestion of food waste for biogas production," Renewable \& Sustainable Energy Reviews, vol. 38, pp. 383-392, 2014.

[14] N. Mosier, R. Hendrickson, N. Ho, M. Sedlak, and M. R. Ladisch, "Optimization of $\mathrm{pH}$ controlled liquid hot water pretreatment of corn stover," Bioresource Technology, vol. 96, no. 18, pp. 1986-1993, 2005.

[15] C. Liu, H. Li, Y. Zhang, and C. Liu, "Improve biogas production from low-organic-content sludge through high-solids anaerobic co-digestion with food waste," Bioresource Technology, vol. 219, pp. 252-260, 2016.

[16] W. Qiao, X. Yan, J. Ye, Y. Sun, W. Wang, and Z. Zhang, "Evaluation of biogas production from different biomass wastes with/without hydrothermal pretreatment," Journal of Renewable Energy, vol. 36, no. 12, pp. 3313-3318, 2011.

[17] R. A. Labatut, L. T. Angenent, and N. R. Scott, "Conventional mesophilic vs. thermophilic anaerobic digestion: Atrade-off between performance and stability?" Water Research, vol. 53, pp. 249-258, 2014.

[18] M. Kim, Y.-H. Ahn, and R. E. Speece, "Comparative process stability and efficiency of anaerobic digestion; mesophilic vs. thermophilic," Water Research, vol. 36, no. 17, pp. 4369-4385, 2002.

[19] V. Kastner, W. Somitsch, and W. Schnitzhoger, "The anaerobic fermentation of FW: a comparison of two bioreactor systems," J. Clean. Prod, vol. 34, pp. 82-90, 2012.

[20] D. Jiang, X. Ge, Q. Zhang, and Y. Li, "Comparison of liquid hot water and alkaline pretreatments of giant reed for improved enzymatic digestibility and biogas energy production," Bioresource Technology, vol. 216, pp. 60-68, 2016.

[21] R. P. Overend, E. Chornet, and J. A. Gascoigne, "Fractionation of Lignocellulosics by Steam-Aqueous Pretreatments," Philosophical Transactions of The Royal Society A Mathematical Physical and Engineering Sciences, pp. 523-536, 1987.

[22] D. D. Nguyen, S. W. Chang, S. Y. Jeong et al., "Dry thermophilic semi-continuous anaerobic digestion of food waste: Performance evaluation, modified Gompertz model analysis, and energy balance," Energy Conversion and Management, vol. 128, pp. 203-210, 2016.

[23] A. Nielfa, R. Cano, M. Vinot, E. Fernández, and M. Fdz-Polanco, "Anaerobic digestion modeling of the main components of organic fraction of municipal solid waste," Process Safety and Environmental Protection, vol. 94, no. C, pp. 180-187, 2015.

[24] Y. Li, Y. Jin, J. Li, H. Li, and Z. Yu, "Effects of thermal pretreatment on the biomethane yield and hydrolysis rate of kitchen waste," Applied Energy, vol. 172, pp. 47-58, 2016.

[25] A. Donoso-Bravo, S. I. Pérez-Elvira, and F. Fdz-Polanco, "Application of simplified models for anaerobic biodegradability tests. Evaluation of pre-treatment processes," Chemical Engineering Journal, vol. 160, no. 2, pp. 607-614, 2010.

[26] S. Achinas and G. J. W. Euverink, "Theoretical analysis of biogas potential prediction from agricultural waste," Resource-Efficient Technologies, vol. 2, no. 3, pp. 143-147, 2016.

[27] APHA., Standard Methods for the Examination of Water and Wastewater, American Public Health Association, Wash, USA, 21st edition, 2005.

[28] APHA, "Standard Methods for the Examination of Water and Wastewater (Methods: 5220 C. Closed Reflux Titrimetric Method), 1998". 
[29] Finnish Standard Association, Determination of chemical oxygen demand (CODCr) in water with closed tube method, oxidation with dichromate. SFS 5504, Finnish Standard Association, Helsinki, Finland, 1988.

[30] O. H. Lowry, N. J. Rosebrough, A. L. Farr, and R. J. Randall, "Protein measurement with the Folin phenol reagent," The Journal of Biological Chemistry, vol. 193, no. 1, pp. 265-275, 1951.

[31] J. Ren, A. Manzardo, A. Mazzi, F. Zuliani, and A. Scipioni, "Prioritization of bioethanol production pathways in China based on life cycle sustainability assessment and multicriteria decision-making," The International Journal of Life Cycle Assessment, vol. 20, no. 6, pp. 842-853, 2015.

[32] A. Mardani, E. K. Zavadskas, K. Govindan, A. A. Senin, and A. Jusoh, "VIKOR technique: A systematic review of the state of the art literature on methodologies and applications," Sustainability, vol. 8, no. 1, pp. 1-38, 2016.

[33] M. M. Yeshanew, L. Frunzo, P. N. Lens, F. Pirozzi, and G. Esposito, "Mass Loss Controlled Thermal Pretreatment System to Assess the Effects of Pretreatment Temperature on Organic Matter Solubilization and Methane Yield from Food Waste," Frontiers in Environmental Science, vol. 4, 2016.

[34] D. Krishna and A. S. Kalamdhad, "Pre-treatment and anaerobic digestion of food waste for high rate methane production - A review," Journal of Environmental Chemical Engineering (JECE), vol. 2, no. 3, pp. 1821-1830, 2014.

[35] S. Mukamel, "Multidimensional femtosecond correlation spectroscopies of electronic and vibrational excitations," Annual Review of Physical Chemistry, vol. 51, pp. 691-729, 2000.

[36] T. Hayashi, W. Zhuang, and S. Mukamel, "Electrostatic DFT map for the complete vibrational amide band of NMA," The Journal of Physical Chemistry A, vol. 109, no. 43, pp. 9747-9759, 2005.

[37] K. Koch, B. Helmreich, and J. E. Drewes, "Co-digestion of food waste in municipal wastewater treatment plants: Effect of different mixtures on methane yield and hydrolysis rate constant," Applied Energy, vol. 137, pp. 250-255, 2015.

[38] G. Esposito, L. Frunzo, A. Giordano, F. Liotta, A. Panico, and F. Pirozzi, "Anaerobic co-digestion of organic wastes," Reviews in Environmental Science and Bio/Technology, vol. 11, no. 4, pp. 325-341, 2012.

[39] B. Deepanraj, V. Sivasubramanian, and S. Jayaraj, "Kinetic study on the effect of temperature on biogas production using a lab scale batch reactor," Ecotoxicology and Environmental Safety, vol. 121, pp. 100-104, 2015. 


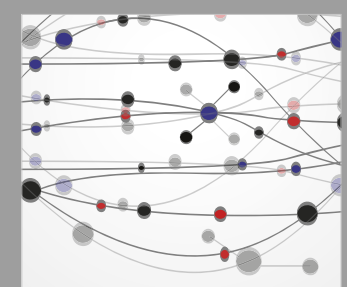

The Scientific World Journal
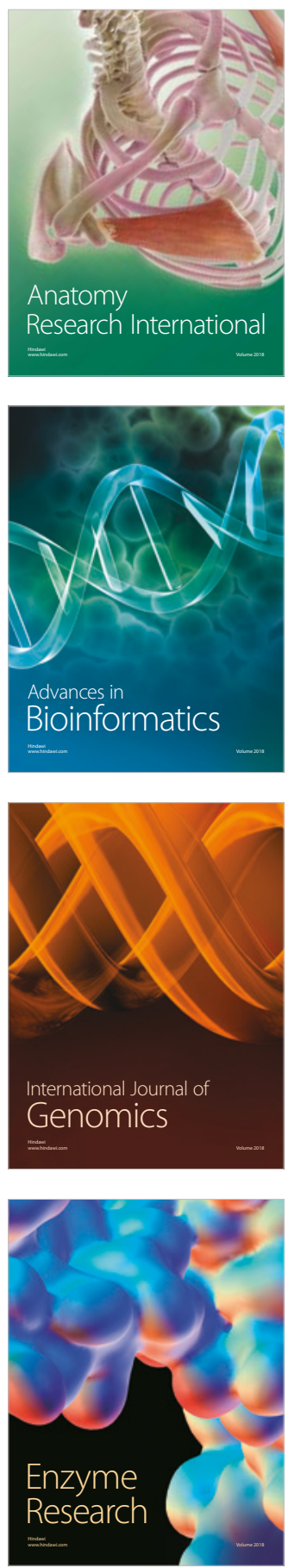
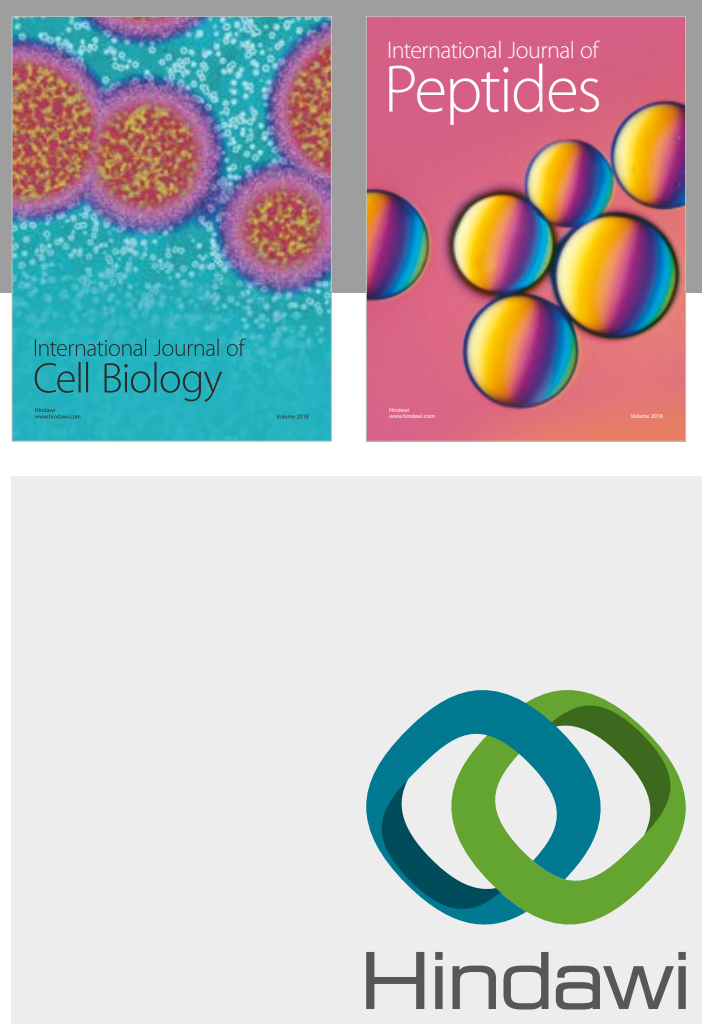

Submit your manuscripts at

www.hindawi.com
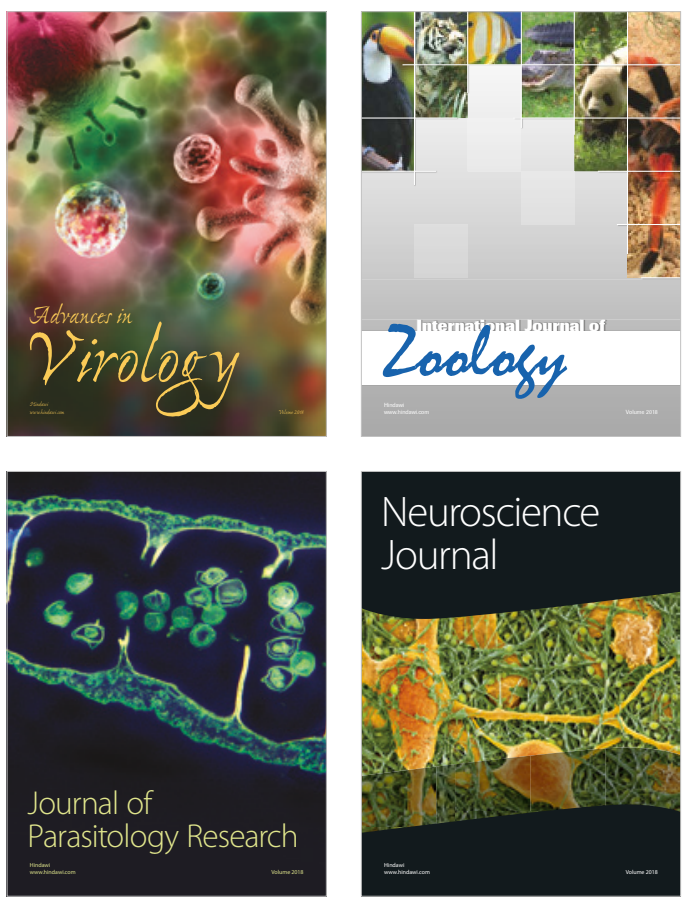
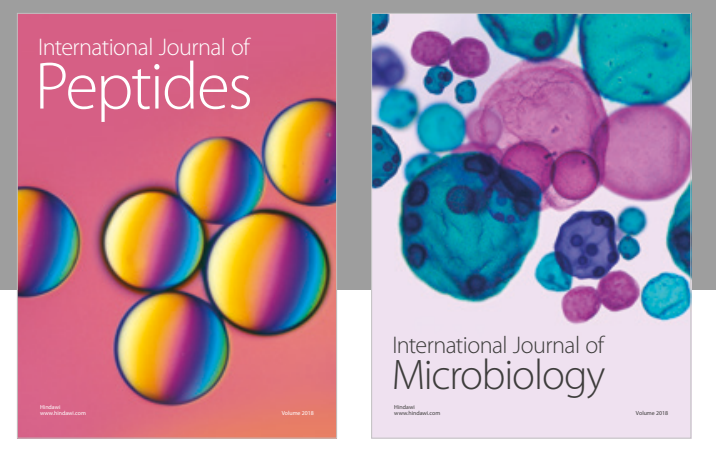

nternational Journal of Microbiology
Journal of
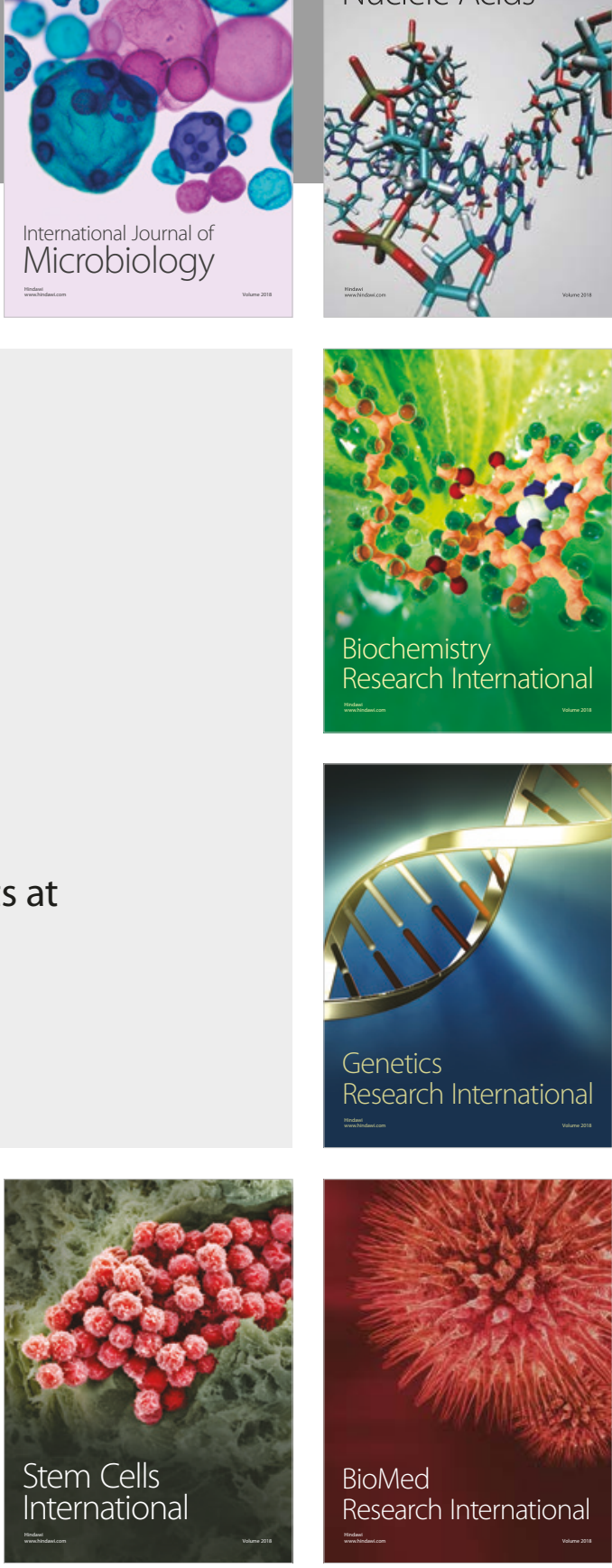
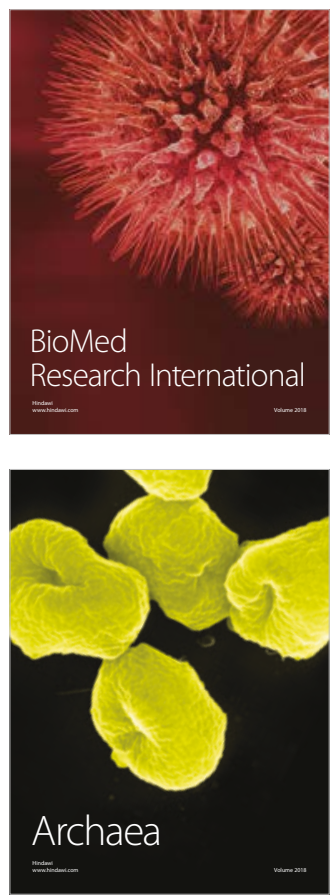